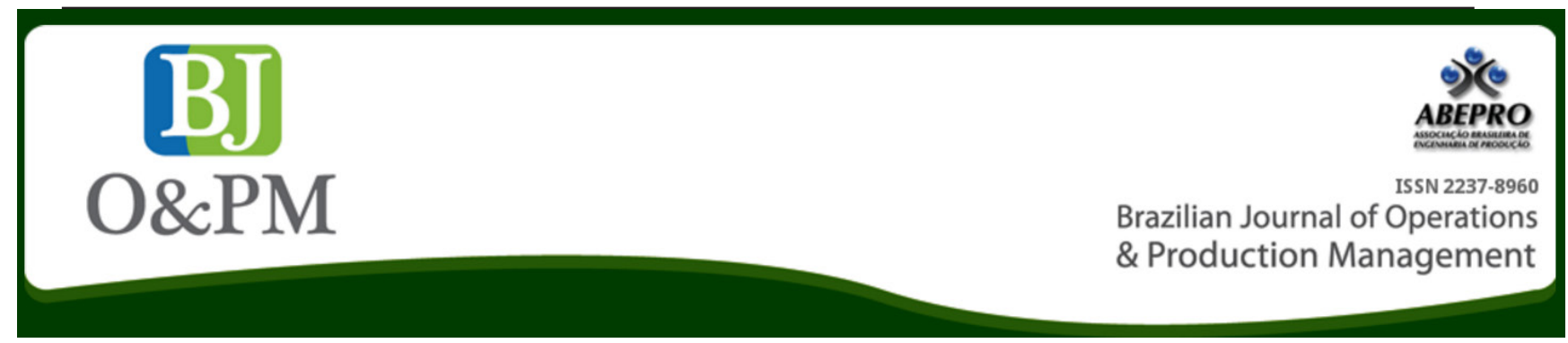

\title{
PERFORMANCE MEASUREMENT OF GREEN SUPPLY CHAIN MANAGEMENT: A LITERATURE REVIEW AND GAPS FOR FURTHER RESEARCH
}

\author{
Gustavo Tietz Cazeria; Rosley Anholon ; Robert Eduardo Cooper Ordoñez ; Olívio Novaski ${ }^{a}$
}

a State University of Campinas (UNICAMP) - Campinas - SP, Brazil

\begin{abstract}
Green Supply Chain Management (GSCM) has been receiving increased attention because of the urgent need of organizations to address sustainability issues as a condition for their competitiveness, and the issue of how performance should be measured becomes crucial. This paperperforms a literature review on an academic basis in order to identify the main subjects and sustainable dimensions of research studies involving the performance measurement of GSCM and the gaps for further research.Sixty three percent of the analyzed papers are associated with framework, mathematical modelling,empirical research and application, and the principal gaps to be exploredare the metrics, measures and integration of the GSCM with existing quality methods. Almost all of these subjects are discussed in an economic and environmental dimension, remaining the social dimension a relevant gap to be explored. Based on this scenario, this paper intends to make a contribution to the academia and professionals of the area.
\end{abstract}

Keywords:supply chain management;green performance; literature review;sustainability. 


\section{INTRODUCTION}

Over the last few decades, a greater amount of individuals are becoming more aware of the environmental problems of the world, including global warming,the use of toxic substance and the decrease in non-renewable resources (LUTHRA et al., 2014). Environmental importance was specially stressed in 1987 when theWorld Commission on Environment and Development published the report Our Common Future, which defines sustainability as the utilization of resources to meet the needs of the present generation without compromising the ability of future generations to meet their own needs (LUTHRA et al., 2014).

In this context, the term "green supply chain management" (GSCM) emerged as the one that most closely linked sustainability concepts and practices into SCM (AHI et SEARCY, 2013, et ASHBY et al., 2012) and it proceeded to be one of the most important approaches in the field of environmental sustainability (HAZEN, 2011 et XUET al., 2013). According to Dubey et Ali (2015), the importance of GSCM is meanly because of the rapid depletion of raw materials, environmental degradation and increased levels of pollution.

The GSCM has being increasingly discussed, recognized and incorporated by industries (SARKIS et al., 2011), and it has being adopted by companies that tend to seek superior environmental performance (DIABAT et GOVINDAN, 2011). According to Ahi et Searcy (2013), there is an increasing recognition that organizations must address the issue of sustainability in their operations, and the management of supply chains is thus receiving increased prominence. According to Jabbour et al. (2014), sustainability has a permanent place in the agendas of approximately $70 \%$ of business leaders and a new management approach called GSCM takes place considering both the internal and the external context of organizations (ARANTES et al., 2014).

On the other hand and according to Zhu et Sarkis (2006), business competitiveness encourages organizations to differentiate themselves from competitors by seeking a better environmental performance without compromising the economic results, considering the entire production chain in a win-win perspective, in which both environmental and economic aspects are simultaneously improved. According to Srivastava (2007), GSCM can reduce the ecological impact of an industrial activity without sacrificing quality, cost, reliability, performance or the efficiency of energy use, thereby meeting environmental regulations and enhancing the overall economic profit.

In this scenario, performance measurement becomes a relevant topic. According to Bai et Sarkis (2014), the evaluation and improvement of the supply chain performance require the development of performance measurement systems and measures. Conventionally, supply chain performance measures have been orientated around cost, time and accuracy. However, organizations are now coming under increased scrutiny from customers and governments regarding their compliance with environmental and social responsibility (SHAW et al., 2010). Even though sustainable performance assessment in SCM is increasing, there is insufficient integration and maturity in this respect in the socioeconomic sphere (CHARDINE-BAUMANN et BOTTA-GENOULAZ, 2014). The importance of performance measurement in the environmental, social and economic dimensions is also discussed by Elkington (1998), who introduced the "triple bottom line" concept - a new equation that reflects the needs of companies to measure the environmental, social and economic performance.

A number of literature reviews on GSCM have been published in the past few years. Some of these reviews have been general and comprehensively covered the entire field, while others have focused on specific aspects (FAHIMNIA et al., 2015). Specifically considering the subject of performance measurement of GSCM, to the best of our knowledge,we found no research paper that provides a review of this topic, specifically. In this way, this paper provides a methodological review for a better understanding of the current state of research studies regarding the subject "performance measurement of GSCM" and answers the following questions: 1) "What are the main subjects addressed by academic research related to the performance measurement of GSCM and what are the issues with the potential to be better exploited?"and 2) "How much of each dimension - economic, social and environmental- is addressed by academic research related to the performance measurement of GSCM and what are the dimensions with the potential to be better exploited?".

To answer these questions, the following objectives were established: 1 ) to analyze the main scientific bases looking for papers related to the performance measurementof GSCM; 2) to perform the screening of papers related to the performance measurementof GSCMand to analyze and classify the results; and, 3) to establish conclusions on the main issues addressed and the gaps to be further researched by the academia.

\section{LITERATURE REVIEW}

\subsection{Definitions and concepts related to GSCM}

The importance of the concepts of supply chain management and environmental management as strategic organizational practices to gain competitive advantage can be easily traced back to the early periods of the environmental management movement of the late 1960s (SARKIS et al., 2011), but it received increased attention especially during the period of the late 1980s and investigations started to 
become more established in the mid-1990s (FAHIMNIA et al., 2015). The GSCM has emerged as an important organizational philosophy to achieve the objectives related to profit and market share of organizations by reducing environmental risks and impacts while improving the ecological efficiency of these organizations and their partners (DIABAT et al., 2013).

A number of possible definitions for the GSCM have been put forth over the past decade, and there is a range of different focuses and purposes related to GSCM with no consensus (ZHU et SARKIS, 2006). According to Lutra et al. (2014), various definitions have been suggested by different researchers and, currently, there is a lack of consensus about the definition and practices for the GSCM (FAHIMNIA et al., 2015). Ahi et Searcy (2013) published a literature review paper focusing purely on the existing definitions for the GSCM. They found a total of twenty-two different definitions published for the GSCM, but no new or integrated definition was proposed.

As the GSCM embraces the SCM, initially this paper will present a definition of SCM. Ahi et Searcy (2013)have analyzed 173 definitions of SCM and they present the definition of Stock et Boyer (2009) as the one that takes into account the high number of key characteristics of the SCM. Therefore, this paper considers the definition according to Stock et Boyer (2009):

\begin{abstract}
"The management of a network of relationships within a firm and between interdependent organizations and business units consisting of material suppliers, purchasing, production facilities, logistics, marketing, and related systems that facilitate the forward and reverse flow of materials, services, finances, and information from the original producer to the final customer with the benefits of adding value, maximizing profitability through efficiencies, and achieving customer satisfaction."
\end{abstract}

Regarding the definition of the GSCM, the one with the highest number of citations in the Scopus database is presented by Srivastava (2007), who defines it as: "integrating environmental thinking into supply chain management, including product design, material sourcing and selection, manufacturing processes, delivery of the final product to the consumers, as well as end-of-life management of the product after its useful life". Luthra et al. (2014) reinforces the importance of the economic criteria presenting GSCM as: "a multidisciplinary issue that emerges mainly from performing environmental management practices in the context of supply chains keeping the economic criteria in their minds."

According to Srivastava (2007), GSCM can be classified based on the methodology, such as thought papers / perspectives, frameworks / approaches, empirical studies, mathematical modelling approaches and reviews. Thought papers / perspectives and frameworks / approaches focus on the necessity and importance of GSCM, define the meaning and scope of various terms and suggest approaches to further explore the area. Empirical studies include case research, field surveys and interviews, field experiments, mail surveys, laboratory experiments and game simulations. Mathematical modelling approaches consist on the tools and techniques that have been used for problem formulation. Reviews consider the existing literature about the various aspects and facets of the GSCM.

Taking into consideration the classification according to the dimension of the GSCM, Elkington (1998) presents the growing need of a company to address issues related to three areas of responsibility - financial, social and environmental - because of the growing pressure from governments and citizens for business to become ever more responsible. This scenario has led to the formulation of a new value formula called 'triple bottom line' that reflects the economic, social and environmental performance as the elements of a new equation to assess and express the value of a company in terms of its 'sustainability'.

Chardine-Baumann et Botta-Genoulaz (2014) have also considered these three dimensions for sustainable development: environmental management, social responsibility and economic contribution. Each of these dimensions is detailed below. These three dimensions are also presented by Wittstruck et Teuteberg (2012), and they are aligned with the "triple bottom line" presented by Elkington (1998). Bellow we show the description of each dimension according to Chardine-Baumann et BottaGenoulaz (2014).

a) Environmental: Environmental management (environmental budget, environmental certification, environmental compliance, worker implications), use of resources (renewable energy, recycled water, inputs from recycling, recyclable outputs, recyclable wastes), pollution (air pollution, water pollution, land pollution, other pollution), dangerousness (dangerous inputs, dangerous outputs, dangerous wastes) and natural environment (eco-systemic services, respect of biodiversity, land use, development of urban and rural areas).

b) Social responsibility: work conditions (employment, work conditions, respect of social dialog, health and security, development of human resources), human rights (child and forced labor, freedom of association, discrimination), social commitment (involvement in local communities, education, culture and technological development, job creation, healthcare, social investment), customer 
issues (marketing and information, healthcare and security, protection of private life, access to essential services) and business practices (fight against corruption, fair-trading, promotion of corporate social responsibility in the sphere of influence).

c) Economic contribution: reliability (customer service, supplier service, reliability of stocks, reliability of estimates), responsiveness (design responsiveness, purchase responsiveness, source responsiveness, production responsiveness, delivery responsiveness, sales responsiveness, return responsiveness, supply chain responsiveness), flexibility (flexibility of suppliers, supply flexibility, production flexibility, delivery flexibility), financial performance (design cost, purchase cost, source cost, production cost, delivery cost, return cost, supply chain cost) and quality (product/ service quality, quality performance of suppliers, production quality).

\subsection{Performance Measurement of GSCM}

According to Taticchi et al. (2010), since the mid1980s, companies have emphasized the growing need of controlling production business processes. Companies have being understanding to compete in continuously changing environments it is necessary monitoringtheir performances.

According to Wong (2009), performance measurement is crucial to better supply the chain management, and the sustainable supply chain performance measurement has its foundations in this emergent work on supply chain performance measurement. According to Vasileiou et Morris (2006), the importance of the sustainability criteria to measure and report supply chain performance has been increased in the current competitive economic, social and environmental scenario.

The performance measurement aspect of green supply chains has been justified by several authors. Rao et Holt (2005) found that greening of the different phases of the supply chain has led to competitiveness and better economic performance.

Liang et al. (2006) have highlighted that, for an effective green supply chain management, the evaluation of the overall performance of the entire chain is crucial. Since greening cannot be achieved overnight, performance measures will reveal at any point the extent to which an organization has invested in its environmental supply chain initiative (OLUGU et al., 2011). Moreover, with the increasing integration of sustainability into SCM, "the question of how to measure supply chain wide sustainability performance is paramount" (SEURING et GOLD, 2013).
According to Hervani et al. (2005), the purposes of the performance measurement of GSCM are: external reporting (economic rent), internal control (better managing the business) and internal analysis (better understanding the business and continuous improvement). These are the fundamental issues that drive the development of frameworks for business performance measurement. In this context, supply chain managers have great power to affect the sustainable performance by making decisions related supplier selection and development, modal and carrier selection, vehicle routing, location decisions, packaging choices and others (CARTER et EASTON, 2011).

In the development of the supply chain management metric system the main steps are establishing the right metrics, linking metrics to strategic objectives and creating a detailed metrics database (FALDU et KRISHNA, 2007). According to Bai et al. (2010), the integration of tangible and intangible performance measures addsmanaging complexity to the supply chain performance.

While the relationship between practices, economic and environmental performance in developed economies has been extensively discussed in literature, the relationships between green practices and performance, especially in developing economy countries, remain relatively unexplored (LAOSIRIHONGTHONG et al., 2013).

\section{METHODOLOGY}

\subsection{Scientific Research Classification}

The classification of this scientific research follows the classical criteria. From the perspective of methods, this research presents deductive characteristics because it analyzes papers published on scientific bases and reaches conclusions based on this information. According to Lakatos et Marconi (2003), deduction allows the emerging og conclusions from true premises. Similar to Silva et Menezes (2005), deduction aims to explain the content of assumptions and facts through reason. Based on Andrade (1999), this method was first introduced by René Descartes, for whom the only way to find a certainty was through the reason - the absolute principle of human knowledge.

Regarding technical procedures, this research can be classified as bibliographic because it uses materials already developed and published, mainly books and scientific papers. According to Gil (2002) and Lakatos et Marconi (2003), the bibliographic research covers the entire bibliography already published in relation to the subject of study. Its purpose is to put the researcher in direct contact with all that has been written, said or filmed about the subject of study.

Considering the approach of the question, this research is classified as qualitative because it has a sequence of activities 
involving data reduction, categorization, interpretation and final conclusion. According to Gil (2002), this procedure sets a qualitative study. Similar to Silva et Menezes (2005), the data base interpretation and the assigning of meanings to it are essential in the qualitative research process, which does not require the use of statistical methods. Based on Godoy (1995), qualitative research does not attempt to enumerate the events studied nor employs statistical instruments in analyzing the data base.

Regarding the nature of this research, it is classified as applied. According to Silva et Menezes (2005), applied research is one that generates knowledge for practical application and aims to solve specific problems.

Finally, regarding the objective, it is classified as exploratory. According to Gil (2002), exploratory research aims to improve ideas or discover intuitions in order to provide greater familiarity with the question.

\subsection{Research Method}

Based on the purpose of this paper, which is to identify papers related toperformance measurement of GSCM and classify them in order to find gaps, issues and opportunities for further studies and researches, a literature review is a valid approach. This helps to identify the conceptual content of the field and guides the study towards theory development (SRIVASTAVA, 2007).

The key words used for data collection were "Green SupplyChain", "performance measurement", "performance assessment", "maturity", "measurement model" and "key performance indicators" (KPI). Five combinations of these key words were used including: (1) Green Supply Chain AND performance measurement, (2) Green Supply Chain AND performance assessment, (3) Green Supply Chain AND maturity, (4) Green Supply Chain AND measurement model and (5) Green Supply Chain AND key performance indicators.

Using the "title, abstract, keywords" search in scientific bases, we collected and stored "journal" papers (conference papers,books and chapters of bookswere excluded) for the defined search terms with maximum published age of ten (10) years. The investigated scientific bases searched were: Web of Science, Emerald, Scopus, Wiley, SciELO and Periódicos Capes.

The initial search on the scientific bases resulted in fortyfive (45) papers. After a detailed analysis and considering only the papers related to GSCM performance, the sample to be studied consisted of forty (40) papers.

The subjects addressed in these papers were identified and classified according to the Table 1 and Table 2. The categories of Table 1are detailed below.
Table 1. Categories used to classify papers based on methodology

\begin{tabular}{|l|}
\hline 1. Framework / model / approach \\
\hline 2. Metrics / measures \\
\hline 3. Integration of GSCM with existing quality methods and tools \\
\hline 4. Literature review \\
\hline 5. Empirical Research / Application \\
Source: The authors own
\end{tabular}

Bellow, there is a description of each category. This classification was elaborated by the authors based on the classification of methodology proposed by Srivastava (2007).

- Framework/approach/model (1): refers to papers whose subjects propose frameworks and approaches to better explore the performance area of GSCM. Model refers to papers that use mathematical tools and techniques for a performance problem formulation for the GSCM;

- Metrics/measures (2): includes papers that discuss the metrics and measures to evaluate the performance of GSCM;

- Integration of GSCM with existing quality methods and tools (3): refers to papers that analyze the performance of GSCM integrated with an existing performance management system (quality, environmental, supply chain, etc.);

- Literature review (4): refers to papers that explore the existing literature about the various aspects and facets of the performance area of GSCM;

- Empirical/Application (5): refers to papers that include case research studies, field surveys and interviews, field experiments, mail surveys, laboratory experiments and game simulations.

Based on sustainable development, the papers were classified according to the three dimensions mention on item "definitions and concepts related to GSCM" (item 2.1). These categories are presented in Table 2.

Table 2. Categories used to classify papers based on sustainable development dimensions

\begin{tabular}{|l|}
\hline 1.Economic \\
\hline 2.Social \\
\hline 3.Environmental \\
\hline
\end{tabular}

Source: Compiled from Chardine-Baumann et Botta-Genoulaz (2014) et Elkington (1998)

\section{RESULTS}

The forty (40) papers mentioned in item "research method" (item 3.2) are detailed in Table 3 below based on their subjects. 


\begin{tabular}{|c|c|c|c|c|}
\hline Item & Reference & Subject & Title & Journal or Magazine \\
\hline 1 & $\begin{array}{l}\text { Acquaye et al. } \\
\text { (2014) }\end{array}$ & $\begin{array}{l}\text { To develop a benchmarking framework to address } \\
\text { issues such as supply chain complexity and visibility, } \\
\text { geographical differences and non-standardized data, } \\
\text { ensuring that the entire supply chain environmental } \\
\text { impact (in terms of carbon) and resource use for all tiers } \\
\text { are evaluated. }\end{array}$ & $\begin{array}{l}\text { Benchmarking carbon } \\
\text { emissions performance in } \\
\text { supply chains }\end{array}$ & $\begin{array}{l}\text { Supply Chain } \\
\text { Management: An } \\
\text { International Journal }\end{array}$ \\
\hline 2 & Ahi et Searcy (2015) & $\begin{array}{c}\text { To identify and analyze the metrics published in the } \\
\text { literature on GSCM and sustainable supply chain } \\
\text { management (SSCM). }\end{array}$ & $\begin{array}{l}\text { An analysis of metrics used to } \\
\text { measure performance in green } \\
\text { and sustainable supply chains }\end{array}$ & $\begin{array}{l}\text { Journal of Cleaner } \\
\text { Production }\end{array}$ \\
\hline 3 & $\begin{array}{l}\text { Ala-Harja et Helo } \\
\qquad(2014)\end{array}$ & $\begin{array}{l}\text { To propose a framework of decisions from the greening } \\
\text { point of view and its impact on performance based } \\
\text { on case analyses from the food industry, mainly } \\
\text { the orderpicking, transportation, warehousing and } \\
\text { distribution. }\end{array}$ & $\begin{array}{l}\text { Green supply chain decisions } \\
\text { - Case-based performance } \\
\text { analysis from the food industry }\end{array}$ & Transportation Research \\
\hline 4 & Aranteset al. (2014) & $\begin{array}{c}\text { To analyze how GSCM practices are induced, both } \\
\text { internally and externally, by focal companies on } \\
\text { their supply chains located in the Brazilian high-tech } \\
\text { segment. }\end{array}$ & $\begin{array}{l}\text { Adoption of Green Supply } \\
\text { Chain Management practices: } \\
\text { mechanisms of induction and } \\
\text { the role of focal companies }\end{array}$ & Production \\
\hline 5 & $\begin{array}{l}\text { Azevedo et al. } \\
\quad \text { (2011) }\end{array}$ & $\begin{array}{l}\text { To investigate the relationships between green } \\
\text { practices of supply chain management and supply } \\
\text { chain performance in the context of the Portuguese } \\
\text { automotive industry. }\end{array}$ & $\begin{array}{c}\text { The influence of green practices } \\
\text { on supply chain performance: A } \\
\text { case study approach }\end{array}$ & Transportation Research \\
\hline 6 & Bai et Sarkis (2014) & $\begin{array}{l}\text { To introduce a methodology to identify sustainable } \\
\text { supply chain key performance indicators (KPI) that } \\
\text { can then be used for the sustainability performance } \\
\text { evaluation of suppliers. }\end{array}$ & $\begin{array}{l}\text { Determining and applying } \\
\text { sustainable supplier key } \\
\text { performance indicators }\end{array}$ & $\begin{array}{l}\text { Supply Chain } \\
\text { Management: An } \\
\text { International Journal }\end{array}$ \\
\hline 7 & Baiet al. (2010) & $\begin{array}{l}\text { To introduce a relatively novel rough set theory } \\
\text { application to aid supplier management based on green } \\
\text { and sustainable supply chain management. }\end{array}$ & $\begin{array}{l}\text { Addressing key sustainable } \\
\text { supply chain management } \\
\text { issues using rough set } \\
\text { methodology }\end{array}$ & $\begin{array}{l}\text { Management Research } \\
\text { Review }\end{array}$ \\
\hline 8 & Baiet al. (2012) & $\begin{array}{l}\text { To introduce a methodology to help evaluate, select } \\
\text { and monitor sustainable supply chain performance } \\
\text { measurement that can be integrated into a } \\
\text { performance management system (PMS). }\end{array}$ & $\begin{array}{l}\text { Evaluating ecological } \\
\text { sustainable performance } \\
\text { measures for supply chain } \\
\text { management }\end{array}$ & $\begin{array}{l}\text { Supply Chain } \\
\text { Management: An } \\
\text { International Journal }\end{array}$ \\
\hline 9 & $\begin{array}{l}\text { Bhagwat et Sharma } \\
(2007)\end{array}$ & $\begin{array}{l}\text { To develop a balanced scorecard for supply chain } \\
\text { management (SCM) that measures and evaluates day- } \\
\text { to-day business operations following four perspectives: } \\
\text { finance, customer, internal business process and } \\
\text { learning and growth. }\end{array}$ & $\begin{array}{l}\text { Performance measurement of } \\
\text { supply chain management: A } \\
\text { balanced scorecard approach }\end{array}$ & $\begin{array}{l}\text { Computerset Industrial } \\
\text { Engineering }\end{array}$ \\
\hline 10 & $\begin{array}{l}\text { Bhattacharyaet al. } \\
\text { (2014) }\end{array}$ & $\begin{array}{l}\text { To delineate a green supply chain (GSC) performance } \\
\text { measurement framework using an intra-organizational } \\
\text { collaborative decision-making (CDM) approach. }\end{array}$ & $\begin{array}{l}\text { Green supply chain } \\
\text { performance measurement } \\
\text { using fuzzy ANP-based } \\
\text { balanced scorecard: a } \\
\text { collaborative decision-making } \\
\text { approach }\end{array}$ & $\begin{array}{l}\text { Production Planning et } \\
\text { Control }\end{array}$ \\
\hline 11 & $\begin{array}{l}\text { Bjorklund; Forslund } \\
\qquad(2013)\end{array}$ & $\begin{array}{l}\text { To investigate the purposes of having environmental } \\
\text { performance measurement systems (EPMS) in logistics } \\
\text { and in what ways the purpose of an EPMS can influence } \\
\text { the focus in the supply chain. }\end{array}$ & $\begin{array}{l}\text { The purpose and focus of } \\
\text { environmental performance } \\
\text { measurements systems in } \\
\text { logistics }\end{array}$ & $\begin{array}{l}\text { International Journal } \\
\text { of Productivity and } \\
\text { Performance Management }\end{array}$ \\
\hline 12 & $\begin{array}{l}\text { Bjorklund et al. } \\
\qquad(2012)\end{array}$ & $\begin{array}{l}\text { To present a framework of dimensions and a practical } \\
\text { example on how environmental performance } \\
\text { measurements can be a success by applying these } \\
\text { dimensions. }\end{array}$ & $\begin{array}{l}\text { Performance measurements in } \\
\text { the greening of supply chains }\end{array}$ & $\begin{array}{l}\text { Supply Chain } \\
\text { Management: An } \\
\text { International Journal }\end{array}$ \\
\hline 13 & $\begin{array}{l}\text { Chardine-Baumann } \\
\text { et Botta-Genoulaz } \\
(2014)\end{array}$ & $\begin{array}{c}\text { To propose a framework for sustainable performance } \\
\text { characterization and an analytical model for sustainable } \\
\text { performance assessment. }\end{array}$ & $\begin{array}{l}\text { A framework for sustainable } \\
\text { performance assessment of } \\
\text { supply chain }\end{array}$ & $\begin{array}{l}\text { Computerset Industrial } \\
\text { Engineering }\end{array}$ \\
\hline 14 & $\begin{array}{l}\text { Chithambaranathan } \\
\text { et al. (2015) }\end{array}$ & $\begin{array}{l}\text { To propose a grey based hybrid framework for } \\
\text { evaluating the environmental performance of service } \\
\text { supply chains by integrating the grey based method } \\
\text { with the ELECTRE and VIKOR approaches. }\end{array}$ & $\begin{array}{c}\text { Service supply chain } \\
\text { environmental performance } \\
\text { evaluation using grey based } \\
\text { hybrid MCDM approach }\end{array}$ & $\begin{array}{l}\text { International Journal of } \\
\text { Production Economics }\end{array}$ \\
\hline 15 & Chuang (2014) & $\begin{array}{l}\text { To present a compound approach with a five-phase } \\
\text { process to assess and improve green performance. }\end{array}$ & $\begin{array}{l}\text { Assessing and improving the } \\
\text { green performance using a } \\
\text { compound approach }\end{array}$ & $\begin{array}{l}\text { Flexible Services and } \\
\text { Manufacturing Journal }\end{array}$ \\
\hline
\end{tabular}




\begin{tabular}{|c|c|c|c|c|}
\hline Item & Reference & Subject & Title & Journal or Magazine \\
\hline 16 & Dey et Cheffi (2013) & $\begin{array}{l}\text { To develop and deploy an analytical framework } \\
\text { for measuring the environmental performance of } \\
\text { manufacturing supply chains. }\end{array}$ & $\begin{array}{l}\text { Green supply chain } \\
\text { performance measurement } \\
\text { using the analytic hierarchy } \\
\text { process: a comparative analysis } \\
\text { of manufacturing organisations }\end{array}$ & $\begin{array}{l}\text { Production Planning et } \\
\text { Control }\end{array}$ \\
\hline 17 & Diabat et al. (2013) & $\begin{array}{l}\text { To explore the practices and performances of the GSCM } \\
\text { based on the GSCM literature and the relationship } \\
\text { between green supply chain practices (initiatives) and } \\
\text { performance outcomes in an automotive industry. }\end{array}$ & $\begin{array}{c}\text { An exploration of green } \\
\text { supply chain practices and } \\
\text { performances in an automotive } \\
\text { industry }\end{array}$ & $\begin{array}{l}\text { International Journal of } \\
\text { Advanced Manufacturing } \\
\text { Technology }\end{array}$ \\
\hline 18 & Dubey et Ali (2015) & $\begin{array}{l}\text { To explore the antecedents of Indian companies } \\
\text { practicing green manufacturing practices and their } \\
\text { impact on extended supply chain performance. }\end{array}$ & $\begin{array}{l}\text { Exploring antecedents of } \\
\text { extended supply chain } \\
\text { performance measures - an } \\
\text { insight from Indian green } \\
\text { manufacturing practices }\end{array}$ & $\begin{array}{l}\text { Benchmarking: An } \\
\text { International Journal }\end{array}$ \\
\hline 19 & Dubey et al. (2015) & $\begin{array}{c}\text { To test the impacts of supplier relationship } \\
\text { management (SRM) and total quality management } \\
\text { (TQM) on environmental performance under the } \\
\text { influence of leadership and the moderation effect of } \\
\text { institutional pressures (IP). }\end{array}$ & $\begin{array}{l}\text { Exploring the relationship } \\
\text { between leadership, } \\
\text { operational practices, } \\
\text { institutional pressures and } \\
\text { environmental performance: } \\
\text { A framework for green supply } \\
\text { chain }\end{array}$ & $\begin{array}{l}\text { International Journal of } \\
\text { Production Economics }\end{array}$ \\
\hline 20 & $\begin{array}{l}\text { El Saadany et al. } \\
(2011)\end{array}$ & $\begin{array}{c}\text { To develop an analytical decision model that is used } \\
\text { to investigate the performance of a supply chain } \\
\text { based on product, process and environmental quality } \\
\text { characteristics. }\end{array}$ & $\begin{array}{l}\text { Environmental performance } \\
\text { measures for supply chains }\end{array}$ & $\begin{array}{c}\text { Management Research } \\
\text { Review }\end{array}$ \\
\hline 21 & $\begin{array}{c}\text { Genovese et al. } \\
(2014)\end{array}$ & $\begin{array}{l}\text { To explore the challenges associated with implementing } \\
\text { supplier environmental performance measurement } \\
\text { models in the context of a global supply chain. }\end{array}$ & $\begin{array}{l}\text { Exploring the challenges } \\
\text { in implementing supplier } \\
\text { environmental performance } \\
\text { measurement models: a case } \\
\text { study }\end{array}$ & $\begin{array}{l}\text { Production Planning et } \\
\text { Control }\end{array}$ \\
\hline 22 & $\begin{array}{l}\text { Hervani et al. } \\
\quad(2005)\end{array}$ & $\begin{array}{l}\text { To introduce and provide an overview of the various } \\
\text { issues related to the environmental performance } \\
\text { measurement of (green) supply chain management. }\end{array}$ & $\begin{array}{l}\text { Performance measurement } \\
\text { for green supply chain } \\
\text { management }\end{array}$ & $\begin{array}{l}\text { Benchmarking: An } \\
\text { International Journal }\end{array}$ \\
\hline 23 & $\begin{array}{l}\text { Jabbour et al. } \\
\text { (2015) }\end{array}$ & $\begin{array}{c}\text { To test a new conceptual model based on the } \\
\text { relationship between quality management (QM), } \\
\text { environmental management maturity (EMM), adoption } \\
\text { of external practices of GSCM and green performance } \\
\text { (GP) with data from } 95 \text { Brazilian companies with ISO } \\
14001 \text {. }\end{array}$ & $\begin{array}{c}\text { Quality management, } \\
\text { environmental management } \\
\text { maturity, green supply } \\
\text { chain practices and green } \\
\text { performance of Brazilian } \\
\text { companies with ISO } 14001 \\
\text { certification: Direct and indirect } \\
\text { effects }\end{array}$ & TransportationResearch \\
\hline 24 & $\begin{array}{l}\text { Jabbour et al. } \\
\qquad(2014)\end{array}$ & $\begin{array}{c}\text { To verify the relationship between the maturity levels } \\
\text { of environmental management and the adoption of } \\
\text { green supply chain management (GSCM) practices by } \\
\text { electronics companies in Brazil. }\end{array}$ & $\begin{array}{l}\text { Mixed methodology to analyze } \\
\text { the relationship between } \\
\text { maturity of environmental } \\
\text { management and the } \\
\text { adoption of green supply chain } \\
\text { management in Brazil }\end{array}$ & $\begin{array}{c}\text { Resources, } \\
\text { ConservationandRecycling }\end{array}$ \\
\hline 25 & Kim et Min (2011) & $\begin{array}{c}\text { To examine whether some countries achieve logistics } \\
\text { efficiency at the cost of compromising environmental } \\
\text { quality. }\end{array}$ & $\begin{array}{l}\text { Measuring supply chain } \\
\text { efficiency from a green } \\
\text { perspective }\end{array}$ & $\begin{array}{c}\text { Management Research } \\
\text { Review }\end{array}$ \\
\hline 26 & $\begin{array}{l}\text { Laosirihongthong et } \\
\text { al. (2013) }\end{array}$ & $\begin{array}{c}\text { To examine the implementation of proactive } \\
\text { and reactive practices in the green supply chain } \\
\text { management (GSCM) and to analyze their impact } \\
\text { on the environmental, economic and intangible } \\
\text { performance. }\end{array}$ & $\begin{array}{l}\text { Green supply chain } \\
\text { management practices and } \\
\text { performance }\end{array}$ & $\begin{array}{c}\text { Industrial Management et } \\
\text { Data Systems }\end{array}$ \\
\hline 27 & Lau (2011) & $\begin{array}{l}\text { To discuss the development and use of a green logistics } \\
\text { performance index (GLPI) for easy comparison of } \\
\text { performance among industries and countries. }\end{array}$ & $\begin{array}{l}\text { Benchmarking green logistics } \\
\text { performance with a composite } \\
\text { index }\end{array}$ & $\begin{array}{l}\text { Benchmarking: An } \\
\text { International Journal }\end{array}$ \\
\hline 28 & Lee et Wu (2014) & $\begin{array}{c}\text { To address the way economic and environmental } \\
\text { performance can be measured simultaneously, taking } \\
\text { a multi-methodological approach for the logistics and } \\
\text { supply chain management. }\end{array}$ & $\begin{array}{l}\text { Integrating sustainability } \\
\text { performance measurement } \\
\text { into logistic and supply } \\
\text { networks: A multi- } \\
\text { methodological approach }\end{array}$ & $\begin{array}{c}\text { The British Accounting } \\
\text { Review }\end{array}$ \\
\hline
\end{tabular}


Brazilian Journal of Operations \& Production Management Volume 14, Número 1, 2017, pp. 60-72 DOI: 10.14488/BJOPM.2017.v14.n1.a7

\begin{tabular}{|c|c|c|c|c|}
\hline Item & Reference & Subject & Title & Journal or Magazine \\
\hline 29 & Linet al. (2014) & $\begin{array}{l}\text { To propose a hybrid approach for the evaluation of the } \\
\text { implementation and performance of the green supply } \\
\text { chain management (GSCM) of a company, including the } \\
\text { hierarchical structure and analytic network process. } \\
\text { Additionally, this study applies the fuzzy set theory to } \\
\text { determine linguistic preferences. }\end{array}$ & $\begin{array}{l}\text { Implementation and } \\
\text { Performance Evaluation } \\
\text { of a Firm's Green Supply } \\
\text { Chain Management under } \\
\text { uncertainty }\end{array}$ & $\begin{array}{l}\text { Industrial Engineering et } \\
\text { Management Systems }\end{array}$ \\
\hline 30 & Lirn et al. (2013) & $\begin{array}{l}\text { To measure the green performance of a port; the } \\
\text { literature is reviewed and a survey is carried out to } \\
\text { identify the performance indicators of major green } \\
\text { ports and to evaluate the overall green performance of } \\
\text { three major ports in Asia. }\end{array}$ & $\begin{array}{l}\text { Green performance criteria for } \\
\text { sustainable ports in Asia }\end{array}$ & $\begin{array}{l}\text { International Journal of } \\
\text { Physical Distribution et } \\
\text { Logistics Management }\end{array}$ \\
\hline 31 & Luthra et al. (2014) & $\begin{array}{l}\text { To introduce and provide an overview of the various } \\
\text { issues related to GSCM and to suggest further scope } \\
\text { and direction of research in this emerging field. }\end{array}$ & $\begin{array}{l}\text { Green supply chain } \\
\text { management implementation } \\
\text { and performance - a literature } \\
\text { review and some issues }\end{array}$ & $\begin{array}{l}\text { Journal of Advances in } \\
\text { Management Research }\end{array}$ \\
\hline 32 & Luthra et al. (2015) & $\begin{array}{l}\text { To identify, analyze and model the Critical Success } \\
\text { Factors (CSFs) to implement GSCM towards } \\
\text { sustainability in industries in the Indian perspective. }\end{array}$ & $\begin{array}{l}\text { An analysis of interactions } \\
\text { among critical success factors } \\
\text { to implement green supply } \\
\text { chain management towards } \\
\text { sustainability: An Indian } \\
\text { perspective }\end{array}$ & Resources Policy \\
\hline 33 & Naini et al. (2011) & $\begin{array}{l}\text { To propose a mixed performance measurement system } \\
\text { using a combination of evolutionary game theory and } \\
\text { the balanced scorecard (BSC) in environmental supply } \\
\text { chain management (ESCM) }\end{array}$ & $\begin{array}{l}\text { Designing a mixed performance } \\
\text { measurement system for } \\
\text { environmental supply } \\
\text { chain management using } \\
\text { evolutionary game theory and } \\
\text { balanced scorecard }\end{array}$ & $\begin{array}{l}\text { Resources, Conservation } \\
\text { and Recycling }\end{array}$ \\
\hline 34 & Olugu et al. (2011) & $\begin{array}{l}\text { To develop a set of measures to evaluate the } \\
\text { performance of the automobile green supply chain. }\end{array}$ & $\begin{array}{l}\text { Development of key } \\
\text { performance measures for the } \\
\text { automobile green supply chain }\end{array}$ & $\begin{array}{l}\text { Resources, } \\
\text { ConservationandRecycling }\end{array}$ \\
\hline 35 & $\begin{array}{l}\text { Pazirandeh et Jafari } \\
\text { (2013) }\end{array}$ & $\begin{array}{l}\text { To evaluate whether or not greening efforts } \\
\text { are dependent on a higher level company-wide } \\
\text { sustainability strategy to be carried out and whether } \\
\text { or not greening efforts lead to any changes in logistics } \\
\text { effectiveness and logistics efficiency. }\end{array}$ & Making sense of green logistics & $\begin{array}{l}\text { Journal of Productivity } \\
\text { and Performance } \\
\text { Management }\end{array}$ \\
\hline 36 & $\begin{array}{l}\text { Rostamzadeh et al. } \\
\text { (2015) }\end{array}$ & $\begin{array}{l}\text { To develop a quantitative evaluation model to measure } \\
\text { the uncertainty of GSCM activities and it applies an } \\
\text { approach based on the VIKOR method aiming to solve } \\
\text { the green multi-criteria decision making (GMCDM) } \\
\text { problem. }\end{array}$ & $\begin{array}{l}\text { Application of fuzzy VIKOR for } \\
\text { evaluation of green supply } \\
\text { chain management practices }\end{array}$ & Ecological Indicators \\
\hline 37 & Shawet al. (2010) & $\begin{array}{l}\text { To review the extant literature and to present a } \\
\text { proposed research agenda to examine whether green } \\
\text { performance measures can be integrated within an } \\
\text { existing supply chain performance framework. }\end{array}$ & $\begin{array}{l}\text { Developing environmental } \\
\text { supply chain performance } \\
\text { measures }\end{array}$ & $\begin{array}{l}\text { Benchmarking: An } \\
\text { International Journal }\end{array}$ \\
\hline 38 & Shenet al. (2013) & $\begin{array}{l}\text { To propose a fuzzy multi criteria approach for the } \\
\text { evaluation of green suppliers based on green supply } \\
\text { chain management (GSCM). }\end{array}$ & $\begin{array}{c}\text { A fuzzy multi-criteria approach } \\
\text { for evaluating green suppliers' } \\
\text { performance in green } \\
\text { supply chain with linguistic } \\
\text { preferences }\end{array}$ & $\begin{array}{l}\text { Resources, Conservation } \\
\text { and Recycling }\end{array}$ \\
\hline 39 & $\begin{array}{l}\text { Stefanelli et al. } \\
\qquad(2014)\end{array}$ & $\begin{array}{c}\text { To present the results of a survey related to GSCM } \\
\text { and environmental performance (EP) conducted on } 80 \\
\text { micro, small and medium enterprises that are suppliers } \\
\text { in the Brazilian bioenergy sector (sugar cane and } \\
\text { ethanol production). }\end{array}$ & $\begin{array}{l}\text { Green supply chain } \\
\text { management and } \\
\text { environmental performance of } \\
\text { firms in the bioenergy sector in } \\
\text { Brazil: An exploratory survey }\end{array}$ & Energy Policy \\
\hline 40 & Zhu et al. (2008) & $\begin{array}{c}\text { To test and compare two measurement models } \\
\text { for the implementation of GSCM practices among } \\
\text { manufacturers in China. }\end{array}$ & $\begin{array}{l}\text { Confirmation of a } \\
\text { measurement model for green } \\
\text { supply chain management } \\
\text { practices implementation }\end{array}$ & $\begin{array}{l}\text { International Journal of } \\
\text { ProductionEconomics }\end{array}$ \\
\hline
\end{tabular}

Source: The authors own

The Figure 1 shows the papers presented in Table 3 sorted by date. The expressive growth of the number of research papers in 2015 and the last two years compared to previous years can be easily identified and this is aligned with the increase in published papers on GSCM. It reinforces the claim that GSCM has been increasingly discussed in the previous years (SARKIS et al., 2011), as well as the performance measurement of GSCM. 


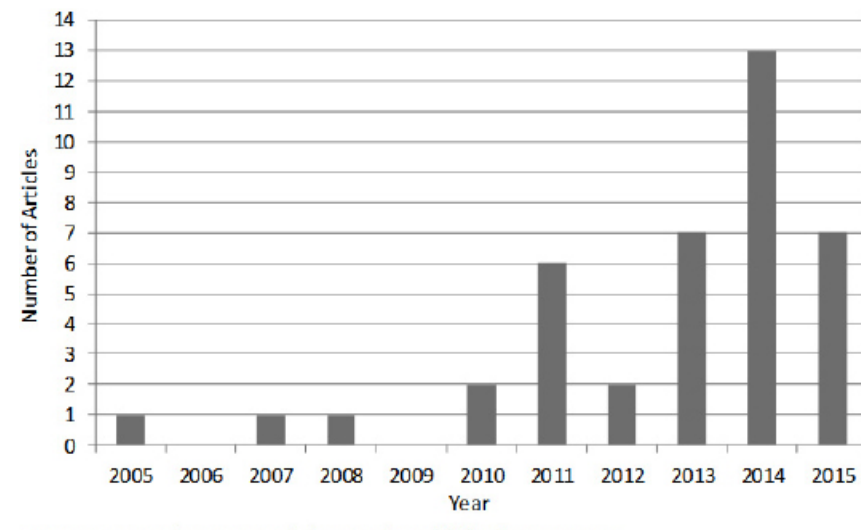

Note: Data regarding 2015 includes articles published up to August.

Figure 1. Distribution of published papers per year Source: The authors own

In addition to the above, considering the database presented on Table 3, we did a division according to the items presented in Table 1 and Figure 2 presents the results of this classification. It shows that $35 \%$ of the papers (fourteen papers) have their subjects associated with "framework/ model/approach" (item 1),28\% of the papers (elevenpapers) have their subjects associated with "empirical/application" (item 2), 15\% of the papers (sixpapers) have their subjects associated with "metrics/measures" (item 3), 15\% of the papers (sixpapers) have their subjects associated with "integration of GSCM with existing quality methods and tools" (item 4) and 7\% of the papers (threepapers) have their subjects associated with "literature review" (item 5).

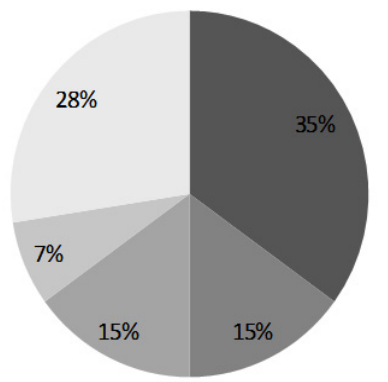

- Framework / model / approach
Metrics / measures
Integration of GSCM with existing
quality methods and tools
Literature review
Empirical / Application

Figure 2.Distribution of papers according to the items presented in Table 3 Source: The authors own

This result demonstrates a high possibility of research studies that can be developed in the item "metrics/ measures" (item 3) and item "integration of GSCM with existing quality methods and tools" (item 4). Regarding "metrics/measures" (item 3), it is important to mention Ahi et Searcy (2015) as, according to them, there is a lack of agreement on how performance should be measured in the area of GSCM.Despite its importance, the "integration of GSCM with existing quality methods and tools" (item 4) also assumes a relevant aspect as organizations are now coming under increased scrutiny from customers and governments regarding their compliance with environmental and social responsibility, and not only regarding the conventional supply chain performance measures orientated towards cost, time and accuracy (SHAW et al., 2010).

Regarding item "literature review" (item 5), only three papers were classified in this item. It is a very small amount of papers because literature reviews take an important role on an emergent subject,such as GSCM,showing an up-todate scenario and identifying gaps on the works carried out. Thereby, this paper intends to make a contribution to this item, presenting the main subjects addressed by the academic research studies related to the performance measurement of GSCM and the issues with the potential to be better exploited.

Most research studies were associated with "framework /model/approach" (item 1) and "empirical research/ application" (item 2). These research studies discuss real subjects, introduce a novel rough set theory application, develop a benchmarking framework or mathematical modelling and provide practical results and comparisons.

Regarding the sustainable development dimensions, the papers presented in Table 3 were classified according to three dimensions: environmental, economic contribution and social responsibility, as described in Table 2 . The result is presented in Figure 3.

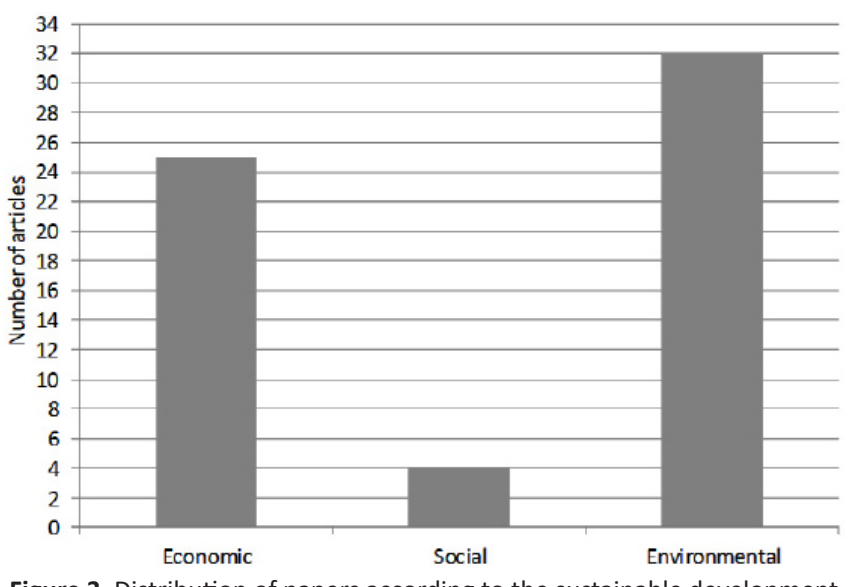

Figure 3. Distribution of papers according to the sustainable development dimensions

Source: The authors own

We can note that the performance of GSCM has been assessed almost equally in the economic and environmental dimensions. It demonstrates that the economic measurement, initially oriented exclusively to the performance measurement systems of the SCM, is linked to the environmental performance measurement regardingthe GSCM. However, the social responsibility dimension can be considered as still being unexplored in the performance measurement of GSCM, and it demonstrates a gap of research studies in this area. By defining the sustainable performance of a practice as the combination of its environmental, economic and social performances (CHARDINE-BAUMANN et BOTTA-GENOULAZ, 2014), we can deduce that new 
research studies on the performance measurements of GSCM should consider the social responsibility dimension in addition to the economic and environmental dimensions currently used for the performance measurement of GSCM. This affirmation is also reinforced by Elkington (1998), who emphasizes the current necessity of the alignment of companies with the "triple bottom line" concept.

\section{CONCLUSION}

As mentioned above, this paper has been engaged in the analysis of the main bases of scientific data in order to identify the main subjects of research studies associated with the performance measurement of GSCM. The search in scientific bases has enabled the finding of forty (40) papers, which were analyzed and categorized into categories structured based on Srivastava(2007) and according to Chardine-Baumann et Botta-Genoulaz(2014) et Elkington (1998).

In light of the results found, we could answer the two proposed questions.Regarding the first question (question 1 in section 1 "Introduction"), the main subject researched on the performance measurementof GSCM is related to "framework/model/approach" (item 1) and the second most researched subject on the performance measurement of GSCM is "empirical research / application" (item 2), with a difference of three papers.Both items presented a significant higher number of scientific research studies than the other subjects, which had three, or at most six, published papers. The mainly noticed gaps are: "metrics/measures" (item 3),"integration of GSCM with existing quality methods and tools" (item 4) and "literature review" (item 5).

Regarding the second question (question 2 in section 1 "Introduction"), it is important to mention that research on performance measurement of GSCM should consider the triad: environmental, social responsibility and economic contribution, regardless of the research item to be explored. Currently, we have found that almost all papers on performance measurement of GSCM take into consideration only the economic and environmental dimensions, and they do not consider the social responsibility dimension.

Thus, we expect that these results and conclusions will be valuable to both the academia and professionals of the area, in this way stimulating further research studies on the area of performance measurement of GSCM.

\section{REFERENCES}

Acquaye, A.; Genovese, A.; Barrett, J.; Koh, S. C. L. (2014). Benchmarking carbon emissions performance in supply chains. Supply Chain Management: An International Journal, Vol.19No.3, pp.306-321.
Ahi, P. et Searcy, C. (2013). A comparative literature analysis of definitions for green and sustainable supply chain management. Journal of Cleaner Production, Vol.52, pp.329-341.

Ahi, P. et Searcy, C. (2015). An analysis of metrics used to measure performance in green and sustainable supply chains. Journal of Cleaner Production, Vol.86, pp.360-377.

Ala-Harja, H. et Helo, P. (2014). Green supply chain decisions - Case-based performance analysis from the food industry. Transportation Research Part E, Vol.69, pp.97-107.

Andrade, M. M. de. (1999). Introdução a Metodologia do Trabalho Científico. 4 Ed., Atlas, SãoPaulo, SP.

Arantes, A. F.; Jabbour, A. B. L. De S.; Jabbour, C. J. C. (2014). Adoption of Green Supply Chain Management practices: mechanisms of induction and the role of focal companies. Production, Vol.24 No.4, pp.725-734.

Ashby, A.; Leat, M.; Hudson-Smith, M. (2012). Making connections: a review of supply chain management and sustainability literature. Supply Chain Management: An International Journal, Vol.17 No.5, pp.497-516.

Azevedo, S. G.; Carvalho, H.; Machado, V. C. (2011). The influence of green practices on supply chain performance: a case study approach. Transportation Research Part E, Vol.47, pp.850-871.

Bai, C. et Sarkis, J. (2014). Determining and applying sustainable supplier key performance indicators. Supply Chain Management: An International Journal, Vol.19 No.3, pp.275-291.

Bai, C.; Sarkis, J.; Wei, X. (2010). Addressing key sustainable supply chain management issues using rough set methodology. Management Research Review, Vol.33 No.12, pp.1113-1127.

Bai, C.; Sarkis, J.; Wei, X.; Koh, L. (2012). Evaluating ecological sustainable performance measures for supply chain management. Supply Chain Management: An International Journal, Vol.17 No.1, pp.78-92.

Bhagwat, R. et Sharma, M. K. (2007). Performance measurement of supply chain management: A balanced scorecard approach. Computers \& Industrial Engineering, Vol.53, pp.43-62.

Bhattacharya, A.; Mohapatra, P.; Kumar, V.; Dey, P. K.; Brady, M.; Tiwari, M. K.; Nudurupati, S. S. (2014). Green supply chain performance measurement using fuzzy ANPbased balanced scorecard: a collaborative decision-making approach. Production Planning \& Control, Vol.25 No.8, pp.698-714.

Bjorklund, M. et Forslund, H. (2013). The purpose and focus of environmental performance measurements 
systems in logistics. International Journal of Productivity and Performance Management, Vol.62 No.3, pp.230-249.

Bjorklund, M.; Martinsen, U.; Abrahamsson, M. (2012). Performance measurements in the greening of supply chains. Supply Chain Management: An International Journal, Vol.17 No.1, pp.29-39.

Carter, R. C. et Easton, P. L. (2011). Sustainable supply chain management: evolution and future directions. International Journal of Physical Distribution \& Logistics Management, Vol.41 No.1, pp.46-62.

Chardine-Baumann, E. et Botta-Genoulaz, V. (2014). A framework for sustainable performance assessment of supply chain. Computers \& Industrial Engineering, Vol.76, pp.138-147.

Chithambaranathan, P.; Subramanian, N.; Gunasekaran, A.; Palaniappan, P. L. K. (2015). Service supply chain environmental performance evaluation using grey based hybrid MCDM approach. International Journal of Production Economics, Vol.166, pp.163-176.

Chuang, S. (2014). Assessing and improving the green performance using a compound approach. Flexible Services and Manufacturing Journal, Vol.26, pp.69-91.

Dey, P. K. et Cheffi, W. (2013). Green supply chain performance measurement using the analytic hierarchy process: a comparative analysis of manufacturing organizations. Production Planning \& Control, Vol.24, pp.702-720.

Diabat, A.etGovindan, K. (2011). An analysis of the drivers affecting the implementation of green supply chain management. Resources, Conservation and Recycling, Vol.55, pp.659-667.

Diabat, A.; Khodaverdi, R.; Olfat, L. (2013). An exploration of green supply chain practices and performances in an automotive industry. International Journal of Advanced Manufacturing Technology, Vol. 68, pp.949-961.

Dubey, R. et Ali, S. S.(2015). Exploring antecedents of extended supply chain performance measures - an insight from Indian green manufacturing practices. Benchmarking: An International Journal, Vol.22, pp.752-772.

Dubey, R.; Gunasekaran, A.; Ali, S. S. (2015). Exploring the relationship between leadership, operational practices, institutional pressures and environmental performance: a framework for green supply chain. International Journal of Production Economics, Vol.160, pp.120-132.

Elkington, J. (1998). Accounting for the triple Bottom Line. Measuring Business Excellence, Vol.2 No.3, pp. 18-22.

El Saadany, A.M.A., Jaber, M.Y. and Bonney, M. (2011). Environmental performance measures for supply chains. Management Research Review, Vol.34 No.11, pp.1202-1221.
Fahimnia, B.; Sarkis, J.; Davarzani, H. (2015). Green supply chain management: a review and bibliometric analysis. International Journal of Production Economics, Vol.162, pp.101-114.

Genovese, A.; Koh, S. C. L.; Kumar, N.; Tripathi, P. K. (2014). Exploring the challenges in implementing supplier environmental performance measurement models: a case study. Production Planning \& Control, Vol.25 No.13-14, pp.1198-1211.

Gil, A. C. (2002). Como Elaborar Projetos de Pesquisa, Atlas, São Paulo, SP.

Godoy, A. S. (1995). Introdução à Pesquisa Qualitativa e Suas Possibilidades. Revista de Administração de Empresas (RAE), Vol.35No.2, pp.57-63.

Hazen, B. T.; Cegielski, C.; Hanna, J. B. (2011). Diffusion of greensupply chain management - examining perceived quality of green reverse logistics. The International Journal of Logistics Management, Vol.22 No.3, pp.373-389.

Hervani, A. A.; Helms, M. M. and Sarkis, J. (2005). Performance measurement for green supply chain management. Benchmarking: An International Journal, Vol.12 No.4, pp.330-353.

Jabbour, A. B.; Jabbour, C.; Govindan, K.; Kannan, D.; Arantes, A. F. (2014). Mixed methodology to analyze the relationship between maturity of environmental management and the adoption of green supply chain management in Brazil. Resources, Conservation and Recycling, Vol.92, pp.255-267.

Jabbour, A. B. L. De S.; Jabbour, C. J. C.; Latan, H.; Teixeira, A. A.; Oliveira, J. H. C. de (2015). Quality management, environmental management maturity, green supply chain practices and green performance of Brazilian companies with ISO 14001 certification: direct and indirect effects. Transportation Research Part E, Vol.74, pp.139-151.

Kim, I.et Min, H. (2011). Measuring supply chain efficiency from a green perspective. Management Research Review, Vol.34, No.11, pp.1169- 1189

Lakatos, E. et Marconi, M. de A. (2003). Fundamentos de Metodologia Científica, 5o ed., Atlas, São Paulo, SP.

Laosirihongthong, T., Adebanjo, D. and Tan, K. C. (2013). Green supply chain management practices and performance. Industrial Management \& Data Systems, Vol.113, No.8, pp.1088-1109.

Lau, K. H. (2011). Benchmarking green logistics performance with a composite index. Benchmarking: An International Journal, Vol.18, No.6, pp.873-896.

Lee, K.et $\mathrm{Wu}, \mathrm{Y}$. (2014). Integrating sustainability performance measurement into logistic and supply 
Brazilian Journal of Operations \& Production Management Volume 14, Número 1, 2017, pp. 60-72 DOI: 10.14488/BJOPM.2017.v14.n1.a7

networks: A multi-methodological approach. The British Accounting Review, Vol.46, pp.361-378.

Liang, L.; Feng, F.; Cook W.D.; Zhu J. (2006). DEA models for supply chain efficiency evaluation. Annals of Operations Research, Vol.145, pp.35-49.

Lin, Y.; Tseng, M.; Chiu, A. S. F.; Wang, R. (2014). Implementation and Performance Evaluation of a Firm's Green Supply Chain Management under uncertainty. Industrial Engineering \& Management Systems, Vol.13 No.1, pp.15-28.

Lirn, T.; Wu, Y. J.; Chen, Y. J. (2013). Green performance criteria for sustainable ports in Asia. International Journal of Physical Distribution \& Logistics Management, Vol.43 No.5/6, pp.427-451.

Lummus, R. R.; Krumwiede, D. W.; Vokurka, R. J. (2001). The relationship of logistics to supply chain management: developing a common industry definition. Industrial Management \& Data Systems, Vol.101 No.8, pp.426-432.

Luthra, S.; Garg, D.; Haleem, A. (2014). Green supply chain management implementation and performance - a literature review and some issues. Journal of Advances in Management Research, Vol.11, No.1, pp.20-46.

Luthra, S.; Garg, D.; Haleem, A. (2015). An analysis of interactions among critical success factors to implement green supply chain management towards sustainability: an Indian perspective. Resources Policy, Vol. 46, No 1, pp. 37-50

Naini, S. G. J.; Aliahmadi, A. R.; Jafari-Eskandari, M. (2011). Designing a mixed performance measurement system for environmental supply chain management using evolutionary game theory and balanced scorecard. Resources, Conservation and Recycling, Vol.55, pp.593-603.

Olugu, E. U.; Wong, K. Y.; Shaharoun, A. M. (2011). Development of key performance measures for the automobile green supply chain. Resources, Conservation and Recycling, Vol.55, pp.567-579.

Pazirandeh, A. et Jafari, H. (2013). Making sense of green logistics. Journal of Productivity and Performance Management, Vol.62 No.8, pp.889-904.

Rao, P. et Holt, D. (2005). Do green supply chains lead to competitiveness and economic performance? International Journal of Operations \& Production Management, Vol.25 No.9, pp.898-916.

Rostamzadeh, R.; Govindan, K.; Esmaeili, A.; Sabaghi, M. (2015). Application of fuzzy VIKOR for evaluation of green supply chain management practices. Ecologicallndicators, Vol.49, pp.188-203.

Sarkis, J.; Zhu, Q.; Lai, K. (2011). An organizational theoretic review of green supply chain management literature. International Journal Production Economics, Vol.130, pp.1-15.

Seuring, S. et Gold, S. (2013). Sustainability management beyond corporate boundaries: from stakeholders to performance. Journal of Cleaner Production, Vol.56, pp.1-6.

Shaw, S.; Grant, D. B.; Mangan, J. (2010). Developing environmental supply chain performance measures. Benchmarking: An International Journal, Vol.17, No.3, pp.320-339.

Shen, L., Olfat, L., Govindan, K., Khodaverdi, R.; Diabat, A. (2013). A fuzzy multi-criteria approach for evaluation green suppliers performance in green supply chain with linguistic preferences", Resources, Conservation and Recycling, Vol.74, pp.170-179.

Silva, E. L. et Menezes, E. M. (2005). Metodologia da Pesquisa. 4o Ed. revisada e atualizada, UFSC, Florianópolis, SC.

Srivastava, S. K. (2007) Green supply-chain management: a state-of-the-art literature review. International Journal of Management Reviews, Vol.9 No.1, pp.53-80.

Stefanelli, N. O.; Jabbour, C. J. C.; Jabbour, A. B. L. de S. (2014). Green supply chain management and environmental performance of firms in the bioenergy sector in Brazil: An exploratory survey. Energy Policy, Vol.75, pp.312-315.

Stock, J. R. et Boyer, S. L. (2009). Developing a consensus definition of supply chainmanagement: a qualitative study. International Journal of Physical Distribution\& Logistics Management, Vol.39, No.8, pp.690-711.

Taticchi, P.; Tonelli, F.; Cagnazzo, L. (2010). Performance measurement and management: a literature review and a research agenda. Measuring Business Excellence, Vol.14, No.1, pp.4-18.

Vasileiou, K. et Morris, J. (2006). The sustainability of the supply chain for fresh potatoes in Britain. Supply Chain Management: An International Journal, Vol.11, No.4, pp.317- 327.

Xu, L.; Mathiyazhagan, K.; Govindan, K.; Haq, A. N.; Ramachandran, N. V.; Ashokkumar, A. (2013). Multiple comparative studies of Green Supply Chain Management: pressures analysis. Resources, Conservation and Recycling, Vol.78, pp.26-35.

Wittstruck, D. et Teuteberg, F. (2012). Understanding the Success Factors of Sustainable Supply Chain Management: Empirical Evidence from the Electrics and Electronics Industry. Corporate Social Responsibility and Environmental Management, Vol.19, No.3, pp.141-158.

Zhu, Q. et Sarkis, J. (2006). An inter-sectorial comparison of green supply chain management in china: drivers and 
practices. Journal of Cleaner Production, Vol. 14, No.5, pp.472-486.

Zhu, Q.; Sarkis, J.; Lai, K. (2008). Confirmation of a measurement model for green supply chain management practices implementation. International Journal of Production Economics, Vol.111, pp.261-273.

Zhu, Q.; Dou, Y.; Sarkis, J. (2010). A portfolio-based analysis for green supplier management using the analytical network process. Supply Chain Management: An International Journal, Vol.15, No.4, pp.306-319. 